\title{
Evaluation of damage caused by Ectinogonia buquetti (Coleoptera: Buprestidae) in dendroenergetic plantations of Eucalyptus camaldulensis
}

\author{
Evaluación del daño causado por Ectinogonia buquetti (Coleoptera: Buprestidae) \\ en plantaciones dendroenergéticas de Eucalyptus camaldulensis
}

\author{
Simón Sandoval a, Jorge Cancino a, Edwin Esquivel a , Eduardo Acuña a*, \\ Rafael Rubilar ${ }^{\text {a }}$, Miguel Espinosa ${ }^{a}$
}

*Autor de correspondencia: ${ }^{a}$ Universidad de Concepción, Facultad de Ciencias Forestales, Laboratorio Biomasa y Bioenergía, Concepción, Chile, casilla 160-C, edacuna@udec.cl

\begin{abstract}
SUMMARY
In a trial established to produce biomass for bioenergy from Eucalyptus camaldulensis Dehnh, ring-debarking in branches and stems caused by Ectinogonia buquetti Spin. (Coleoptera: Buprestidae) was detected. Larvae of this native insect were recently detected in Eucalyptus sp. wood in central Chile (Valparaíso Region). This is the first document describing the damage caused by the adult insect on the bark of Eucalyptus camaldulensis seedlings. This report presents the methodology developed to evaluate damage and describes the frequency and intensity of the damage based on the lost leaf area. In some experimental units, more than $65 \%$ of trees presented damage, where the average leaf area lost per tree was higher than $28 \%$. Moreover, a direct relation between the average damage per tree level and the attack frequency per experimental unit was detected, and both were inversely related to plantation density. The drop in the photosynthetic surface area will affect biomass yield in a magnitude that may only be estimated through successive measurements.
\end{abstract}

Key words: ring-debarking, dendroenergy, foliar damage evaluation, foliage loss.

\section{RESUMEN}

En un ensayo establecido para producir biomasa para bioenergía a partir de Eucalyptus camaldulensis Dehnh, fue detectado el anillado y descortezado en ramas y tallos causado por Ectinogonia buquetti Spin. (Coleoptera Buprestidae). Las larvas de este insecto nativo fueron detectados recientemente en madera de Eucalyptus sp. en el centro de Chile (región de Valparaíso). Este es el primer documento que describe el daño causado por el insecto adulto en la corteza de plántulas de Eucalyptus camaldulensis. En este informe se presenta la metodología desarrollada para evaluar los daños y describe la frecuencia y la intensidad de los daños sobre la base del área foliar perdida. En algunas unidades experimentales, más del 65 \% de los árboles presentan daños, donde el área foliar promedio, pérdida por árbol, fue mayor que $28 \%$. Al parecer, existe una relación directa entre el daño promedio a nivel de árbol y la frecuencia de los ataques a nivel de unidad experimental, y ambos están inversamente relacionados con la densidad de plantación. La caída en el área de la superficie fotosintética afectará el rendimiento de biomasa en una magnitud que sólo podrá ser estimada en mediciones sucesivas.

Palabras clave: descortezado, dendroenergía, evaluación del daño foliar, pérdida foliar.

\section{INTRODUCTION}

The use of non-conventional renewable energy sources is becoming increasingly important around the world, and particularly in Chile. Chilean legislation required that electricity companies gradually increase the volume of non-conventional renewable fuels, between 2010 and 2014 by $5 \%$; increasing by $0.5 \%$ per year starting in 2015, reaching $10 \%$ by 2024 (Ley 20257 2008). Forest biomass is one source of non-conventional renewable energy in Chile with enormous potential to help reach this goal (Bertran and Morales 2008). Forestry biomass can be obtained from the byproducts produced during tree harvesting and silvicultural activities (pruning and thinning), from remo- vals of harvesting residues, and from wood transformation processes (i.e. lumber- and pulp-mills) residues, as well as directly from plantations established to produce biomass for energy generation.

Although an extensive surface area in Chile is covered by commercial stands of Pinus radiata D. Don and Eucalyptus spp., covering more than two million hectares (INFOR 2012), their principal objective is to support the wood industry for international exports. However, the byproducts from harvesting, silvicultural activities and transformation processes are generally not available to the utility companies because they are used directly as energy by the forest companies. Thus, new sources of lignocellulosic biomass -to be used for bioenergy- are needed. 
In a research project designed to find new non-conventional energy sources, trials were established in three locations in Biobío Region in Chile on sites varying in soil and climatic conditions. The experimental plots were established in August 2007 with the tree species Acacia melanoxylon R. Br., Eucalyptus camaldulensis Dehnh, Eucalyptus globulus Labill and Eucalyptus nitens (Deane et Maiden) at densities of 5,000, 7,500 and 10,000 trees per hectare. Eight months after establishment, the insect Ectinogonia buquetti Spinola (Coleoptera: Buprestidae) was detected in one of these trials, located in the inner valley of the Chilean Coastal Mountains feeding on the bark of branches and stems, and on the upper part of the seedlings of Eucalyptus camaldulensis (Valdebenito et al. 2009). The insect is distributed naturally between Santiago and Biobío Region (Moore 1994). The presence of this native insect in plantations of exotic tree species in Chile was reported by Gara et al. (1980) for Pinus radiata and more recently by Piontelli et al. (2006) for Eucalyptus sp. Valdebenito et al. (2009) identified the insect and estimated the number of affected Eucalyptus camaldulensis individuals. Outbreaks of herbivorous insects are common in Eucalyptus spp. plantations and have been described as the main damaging pests of eucalypts including both native and introduced herbivore insects (Eyles et al. 2013). Therefore, the aim of this article is to report the frequency and intensity of the damage produced by Ectinogonia buquetti, which were estimated by means of the measurement of a series of variables in the damaged plants, including the foliar surface affected in experimental plots with Eucalyptus camaldulensis. In short-rotation woody crops for energy production, the potential loss of productivity by unexpected insect attack may affect expected biomass yield, therefore to obtain better information on biotic risks to estimate productivity losses appears as necessary. Our hypothesis is that the magnitude of productivity loss for damaged trees will be directly related to foliage defoliation and reductions of leaf area, but this effect will also depend on stocking.

\section{METHODS}

Experimental design. The trial was located in the east Coastal Range piedmont in the north of Biobío Region in Chile ( $36^{\circ} 17^{\prime} \mathrm{S} 72^{\circ} 22^{\prime} \mathrm{W}$ ), in an area previously occupied by a Pinus radiata plantation. The main objective of this trial was to develop protocols for biomass production intended for the generation of bioenergy from short rotation woody crops established at high densities. The site was planted during August 2007 with containerized 1:0 seedlings; the species Acacia melanoxylon, Eucalyptus camaldulensis and Eucalyptus globulus were established at densities of 5,000, 7,500 and 10,000 seedlings per hectare. The plots were fertilized with nitrogen, phosphorus and potassium (NPK) one month after planting; weed control was applied in November 2009. Soil is of granite origin and belongs to the order Alfisols (Carrasco et al. 1993); topography is flat to wavy. The climate is dry with annual precipitation not over $700 \mathrm{~mm}$ and temperatures which fluctuate between 0 and $32{ }^{\circ} \mathrm{C}$ (DGAC 2013). The experimental plots are surrounded by Pinus radiata plantations, same age as the experimental plantation, located close to a mature stand of Eucalyptus globulus and fragments of a deciduous-type native forest. Before establishing the trial, the area was completely cleared of harvesting residues. Before planting, the soil was subsoiled to a depth of 0.8 $\mathrm{m}$ and afterwards raked. The plantation was established following a randomized complete block design with three replicates. Each experimental unit had an area of $25 \times 25 \mathrm{~m}$ with a central unit of 49 plants.

To evaluate the magnitude and intensity of the damage of Ectinogonia buquetti in Eucalyptus camaldulensis, in November 2009, the stump diameter ( $D$ in mm, measured at $10 \mathrm{~cm}$ from the soil surface), the height of the damage closest to the main stem base and the insertion height of each damaged branch located below the stem damage were recorded for each affected plant in each experimental unit. When damage was present in the branches, a total loss of foliage of each damaged branch was assumed. When ring-debarking was located on the stem, a total loss of foliage on the stem and on all the branches located above this point and the seedling apex was assumed. Based on these data, we estimated the total damage as the total lost leaf area (figure 1).

Leaf loss at tree level was evaluated based on the foliage total amount of a sample of undamaged trees randomly selected in each experimental unit, in which $D$, total tree height and length, number of leaves and insertion height for each branch were recorded. The leaf area for a sample of leaves was measured, differentiating between leaves coming from the stem and those from the branches. Using this information, the leaf area for each branch and the accumulated leaf area between branch insertion height and the apex in undamaged trees were modeled. Leaf area lost due to insect was estimated by fitting the following six relations: total seedling height $-D(1)$, branch length - branch insertion height (2), number of leaves per branch - branch length (3), live crown height $-D^{2} \times$ tree height (4), total foliar area- $D^{2} \times$ height (5), and relative foliar area-relative height (6). All these relations were fitted using the NLIN procedure of SAS software (SAS Institute Inc 2009).

Total seedling height as a function of $D$ was estimated by:

$$
H_{i}=b_{0}+b_{1} D_{i}^{b_{2}}
$$

where $H_{i}$ is total tree height $(\mathrm{cm})$ and $D_{i}$ is the stump diameter of the-ith tree; $b_{0}, b_{1}$ and $b_{2}$ are regression parameters. Here, the parameter $b_{0}$ was restricted to estimating a height of $10 \mathrm{~cm}$ when the apex of the tree was zero because at that height $D$ was zero. Additionally, since $H-D$ relationship depends on stand density, the model (1) was fitted for each plantation density level. 
The length of each branch was estimated as a function of the relative height at branch insertion into the stem by:

$$
\frac{L_{\text {branch j }}}{h_{\text {branch j }}}=b_{0}+b_{1}\left(\frac{H_{i}-h_{\text {branch j }}}{H_{i}}\right)^{b_{2}}+b_{3}\left(\frac{H_{i}-h_{\text {branch j }}}{H_{i}}\right)^{b_{4}}
$$

where $L_{b r a n c h ~}$ and $H_{\text {branch } j}$ correspond to the length and height at which the $j$-th branch is inserted into the stem, respectively; $b_{0}, b_{1}, b_{2}, b_{3}$ and $b_{4}$ are parameters to be estimated in the regression model.

The number of leaves on each branch was determined as a function of branch length by:

$$
\mathrm{N}_{\text {leaves } \mathrm{j}}=\mathrm{b}_{1} \mathrm{~L}_{\text {branch } \mathrm{j}} \mathrm{b}_{2}
$$

where $N_{\text {leaves } j}$ is the number of leaves estimated for the $j$-th branch in the $i$-th tree; $b_{1}$ and $b_{2}$ are regression parameters.

The height of the living crown of each tree $h_{\text {crown } i}$ was estimated by:

$$
\mathrm{H}_{\mathrm{i}}-\mathrm{h}_{\text {crown i }}=\mathrm{b}_{1}\left(\mathrm{D}_{\mathrm{i}}^{2} \mathrm{H}_{\mathrm{i}}\right)^{\mathrm{b}_{2}}
$$

and the total foliar area for each tree by:

$$
\mathrm{S}_{\text {total foliar i }}=\mathrm{b}_{1}\left(\mathrm{D}_{\mathrm{i}}^{2} \mathrm{H}_{\mathrm{i}}\right)^{\mathrm{b}_{2}}
$$

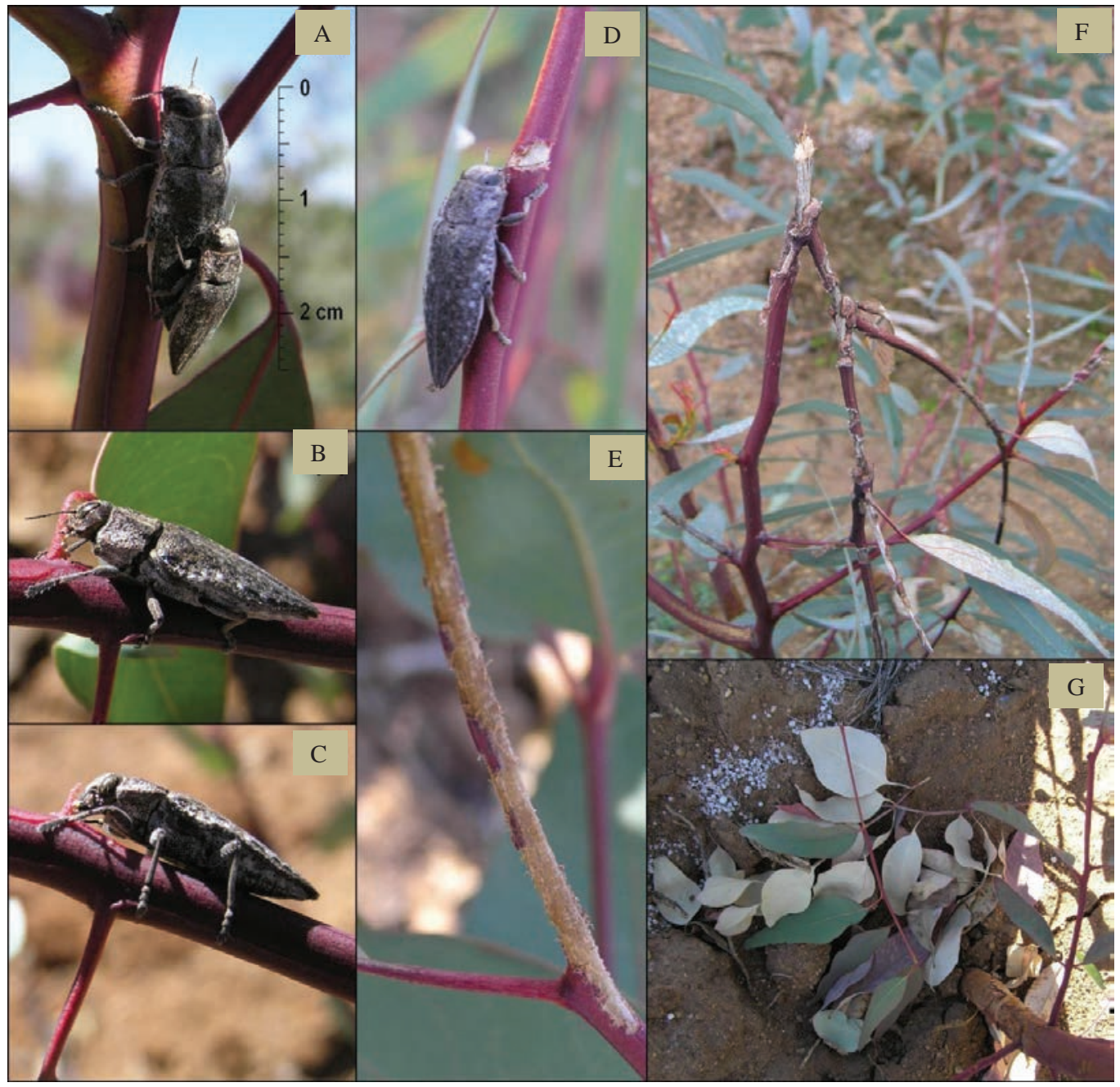

Figure 1. Images of Ectinogonia buquetti and damage caused in Eucalyptus camaldulensis. A): mating pair on the stem, showing the clear size difference between the male and female; B, C) insect consuming a leaf petiole; D) insect feeding on the stem's bark, and causing damage which can extend to large areas (E); F) damaged stem that later is broken by the wind; G): broken fallen branches on the ground.

Imágenes de E. buquetti y del daño causado en E. camaldulensis. A): pareja de insectos sobre el fuste, se muestra la diferencia de tamaño entre el macho y la hembra; B) insecto consumiendo el pecíolo de la hoja antes de su caída (C); D) insecto alimentándose de la corteza del fuste, y causando daños que se puede extender a áreas grandes (E); F) daño a fuste que más tarde es quebrado por acción mecánica del viento; G): ramas quebradas sobre la superficie del suelo. 
The foliar surface area accumulated between the apex of the tree and a particular height along the stem was estimated by:

$$
\frac{S_{\text {foliar i }}}{S_{\text {total foliar i }}}=b_{1}\left(\frac{\left(H_{i}-h_{\text {crown i }}\right)-\left(h_{\text {branch j }}-h_{\text {crown i }}\right)}{H_{i}-h_{\text {crown i }}}\right)^{b_{2}} \text { [6] }
$$

where $S_{\text {foliar } i} / S_{\text {total foliar } i}$ was the ratio of foliar area accumulated between the height of the branch $h_{\text {branch } j}$ and the top of the plant on the $i$-th tree.

These equations were used to determine the foliar area lost due to damage caused by the insect, in a sequence that depended on the type of damage to be analyzed. There were two different estimation sequences, one for individual branches and the other for damage caused on the stem. In both, in the first step the total tree height was estimated from the measured $D$ (equation 1 ). To estimate the damage on one individual branch, the branch length was estimated as a function of the height of its insertion into the stem (equation 2), subsequently the number of leaves was estimated as a function of the length (equation 3 ), and finally the surface area was estimated as the product between the number of leaves and the average foliar area per leaf. To estimate the foliage loss due to stem damage, we estimated the live crown height (equation 4) and the tree total foliage area (equation 5), and finally we estimated total foliage area lost between the height of the damage and the tree apex (equation 6).

Data analyses. Data were analyzed as a complete randomized blocks design, where the three stand density levels were considered as treatments. Tukey's test was applied when necessary. The average foliar area lost per tree, attack frequency and intensity of the damage, as measured by the total foliar surface with damage in relation to total foliar surface per experimental unit, were analyzed. Since foliar area and attack frequency were expressed as percentages, they were normalized using the arcsine transformation (Zar 2010). The probable Block-density interaction was evaluated using the additive test of Tukey. The hypothesis associated to the test assumes that the Block-density effect is additive, i.e. there is no interaction between the two factors $\left(H_{0}: \lambda=0\right)$.

\section{RESULTS}

There was an inverse relationship between damage frequency and stocking. At lower stockings a higher frequency attack was observed on experimental units (tables 1 and 2). Therefore, with 5,000 plants per hectare, on average more than $65 \%$ of the trees presented damage, a frequency that is significantly higher than those values found at the other two density levels $(p(F)=0.0117)$. However, the role of plantation density on total foliar area loss was not completely clear. Even though the average percentage of foliar area loss per tree follows the same tendency of an inverse relation with density (i.e. higher damage at a lower plantation density), and varies between $25 \%$ and $18 \%$ for the lower and higher plantation density levels, respectively. The difference between densities was not significant due to the large variability of damage among trees within each experimental unit. Although, until the present time the role of plantation density is not clear, apparently there exists a direct relation between the average damage per tree and the attack frequency at the experimental unit level, and both are inversely related to plantation density. The role that plantation density will play once intra-specific competition begins on the site is unknown. At high densities, the tree stress level will increase, though it is unknown what effects this will produce on insect behavior.

At the experimental unit level, the proportion of foliar area damaged showed the same inverse relation with plantation density as that observed at tree level, i.e. higher plantation density had lower levels of foliar area loss.

Table 1. Number of undamaged and damaged trees by Ectinogonia buquetti and corresponding leaf area index per plot.

Número de árboles dañados y no dañados y su correspondiente índice de área foliar por unidad experimental.

\begin{tabular}{|c|c|c|c|c|c|c|c|c|c|}
\hline \multirow{2}{*}{ Block } & \multirow{2}{*}{ Plot } & \multirow{2}{*}{$\begin{array}{l}\text { Nominal density } \\
\quad\left(\text { trees }^{-1}{ }^{-1}\right)\end{array}$} & \multicolumn{4}{|c|}{ Number of trees per plot } & \multicolumn{3}{|c|}{ Estimated leaf area index } \\
\hline & & & Undamaged & Damaged & Dead & Total & Current & Loss & Total \\
\hline 1 & 4 & 5,000 & 12 & 37 & 0 & 49 & 0.4106 & 0.1356 & 0.5462 \\
\hline 1 & 8 & 7,500 & 22 & 27 & 0 & 49 & 0.5953 & 0.1447 & 0.7399 \\
\hline 1 & 3 & 10,000 & 25 & 24 & 0 & 49 & 0.9151 & 0.0988 & 1.0139 \\
\hline 2 & 2 & 5,000 & 25 & 20 & 4 & 49 & 0.4847 & 0.0332 & 0.5179 \\
\hline 2 & 4 & 7,500 & 36 & 6 & 7 & 49 & 0.9300 & 0.0162 & 0.9462 \\
\hline 2 & 5 & 10,000 & 35 & 12 & 2 & 49 & 1.3161 & 0.0308 & 1.3469 \\
\hline 3 & 8 & 5,000 & 11 & 34 & 4 & 49 & 0.4683 & 0.1101 & 0.5784 \\
\hline 3 & 1 & 7,500 & 23 & 24 & 2 & 49 & 0.9757 & 0.0976 & 1.0733 \\
\hline 3 & 6 & 10,000 & 29 & 20 & 0 & 49 & 0.9961 & 0.0890 & 1.0851 \\
\hline
\end{tabular}


Thus, at 5,000 plants per hectare, $16.8 \%$ of the total foliar area of the experimental units is lost due to insect damage; this damage level is significantly superior to that found at the highest plantation density. The modeling strategy used to estimate the foliar area lost due to insect damage seems to be reliable (table 3). All the estimators obtained for the six fitted models are significant and emulate the tendency of the observed data (figure 2). Even though the experimental plots were recently established, plantation density already has apparent effects on the height- $D$ relationship;

Table 2. Damage frequency and intensity of damage caused by Ectinogonia buquetti per tree and experimental unit $\left({ }^{1}\right)$.

Frecuencia e intensidad de daño causado por Ectinogonia buquetti en árboles y a nivel de unidad experimental.

\begin{tabular}{|c|c|c|c|}
\hline \multirow{2}{*}{$\begin{array}{c}\text { Analysis level } \\
\text { Source of variation }\end{array}$} & \multirow{2}{*}{$\begin{array}{c}\text { Tree } \\
\text { Foliar area lost (\%) }\end{array}$} & \multicolumn{2}{|c|}{ Experimental unit } \\
\hline & & Attack frequency (\%) & Foliar area loss (\%) \\
\hline \multicolumn{4}{|l|}{ Stand density (trees ha-1) } \\
\hline 5,000 & $24.7 \mathrm{a}$ & $65.2 \mathrm{a}$ & $16.8 \mathrm{a}$ \\
\hline 7,500 & $20.4 \mathrm{a}$ & $40.2 \mathrm{~b}$ & $10.1 \mathrm{ab}$ \\
\hline 10,000 & $17.8 \mathrm{a}$ & $38.4 \mathrm{~b}$ & $6.7 \mathrm{~b}$ \\
\hline \multicolumn{4}{|l|}{ Block } \\
\hline 1 & 28.6 a & 59.9 a & $18.0 \mathrm{a}$ \\
\hline 2 & $11.6 \mathrm{~b}$ & $28.1 \mathrm{~b}$ & $3.5 \mathrm{~b}$ \\
\hline 3 & $22.8 \mathrm{a}$ & 55.8 a & $12.1 \mathrm{a}$ \\
\hline \multicolumn{4}{|l|}{$P(F)$} \\
\hline Stand density & 0.1840 & $0.0117^{*}$ & $0.0268 *$ \\
\hline Block & $0.0094 *$ & $0.0068^{*}$ & $0.0051^{*}$ \\
\hline$P(\lambda)$ & 0.5095 & 0.9651 & 0.5060 \\
\hline
\end{tabular}

$\mathrm{P}(\mathrm{F})$ : observed probability associated with each factor $(*$ : indicates the effects are significant). $\mathrm{P}(\lambda)$ : probability associated with the additive test of Tukey. Different letters in each column indicate significant differences (Tukey, $P<0.05$ ).

$\left.{ }^{1}\right)$ : The information presented here corresponds to untransformed data.

Table 3. Parameter estimates for the six fitted models developed to estimate foliar area loss due to debarking caused by Ectinogonia buquetti on Eucalyptus camaldulensis.

Parámetros estimados para los seis modelos ajustados para estimar pérdida de área foliar debido al descortezado causado por Ectinogonia buquetti en Eucalyptus camaldulensis.

\begin{tabular}{|c|c|c|c|c|c|c|c|}
\hline \multirow{2}{*}{ Dependent variable } & \multicolumn{5}{|c|}{ Regression parameters } & \multirow{2}{*}{$n$} & \multirow{2}{*}{ RMSE } \\
\hline & $b_{0}$ & $b_{1}$ & $b_{2}$ & $b_{3}$ & $b_{4}$ & & \\
\hline$[1] H_{(5,000)}$ & 10 & $20.0770 *$ & $0.6613^{*}$ & & & 65 & 36.52 \\
\hline [1] $H_{(7,500)}$ & 10 & $20.9854 *$ & $0.6566^{*}$ & & & 22 & 39.05 \\
\hline$[1] H_{(10,000)}$ & 10 & $52.5417^{*}$ & $0.3525 *$ & & & 30 & 30.30 \\
\hline [1] $H_{\text {(average) }}$ & 10 & $26.6594 *$ & $0.5712^{*}$ & & & 117 & 35.36 \\
\hline [2] $L_{\text {branch }} / h_{\text {branch }}$ & $0.2601^{*}$ & $3.9473^{*}$ & $3.6675^{*}$ & $28.3503^{*}$ & $41.6221^{*}$ & 535 & 0.66 \\
\hline [3] $N_{\text {leaves }}$ & & $0.1497^{*}$ & $1.2825^{*}$ & & & 535 & 7.99 \\
\hline [4] $S_{\text {foliar }} / S_{\text {total foliar }}$ & & $0.9552 *$ & $1.8523 *$ & & & 535 & 0.07 \\
\hline [5] $H-h_{\text {crown }}$ & & $1.0513^{*}$ & $0.4396 *$ & & & 27 & 15.16 \\
\hline [6] $S_{\text {total foliar }}$ & & $14.1006^{*}$ & $0.6030 *$ & & & 27 & $3,360.68$ \\
\hline
\end{tabular}

RMSE: root mean square residual; *: indicates parameter is significant $(P<0.05)$. 

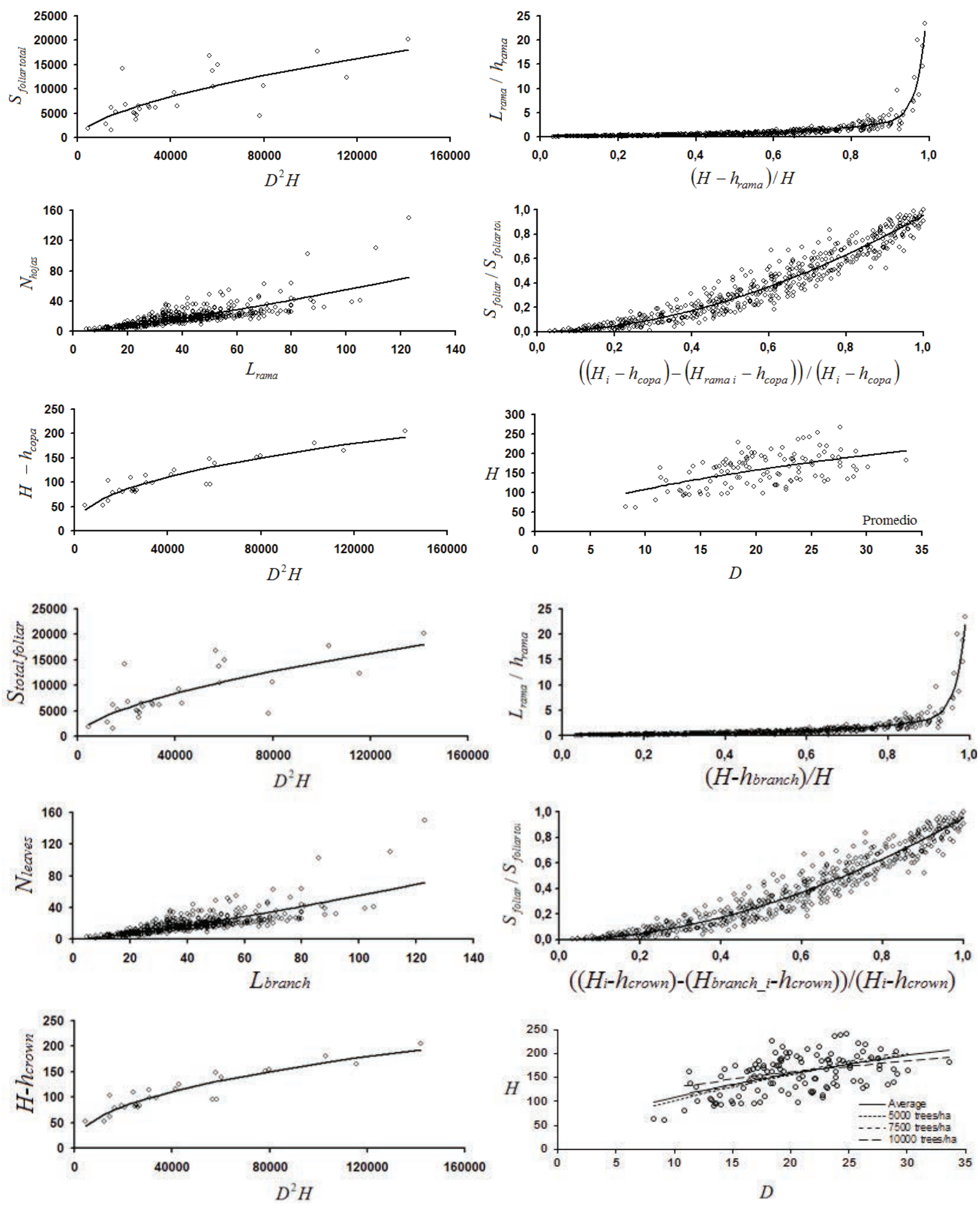

Figure 2. Graphical representation of the six models fitted using data from trees undamaged by Ectinogonia buquetti (units: $H, h_{\text {branch }}$ and $h_{\text {crown }}(\mathrm{cm}) ; D(\mathrm{~mm}) ; S_{\text {foliar }}$ and $S_{\text {total foliar }}\left(\mathrm{cm}^{2}\right)$.

Representación gráfica de los seis modelos ajustados usando los datos de árboles sin daño (unidades: $H, h_{\text {branch }} \mathrm{y} h_{\text {crown }}(\mathrm{cm})$; $D(\mathrm{~mm}) ; S_{\text {foliar }}$ and $S_{\text {total foliar }}\left(\mathrm{cm}^{2}\right)$. 
the estimators of this relationship differ clearly between the density of 10,000 plants per hectare and the other two densities which are basically the same (table 3).

\section{DISCUSSION}

Globally, forest plantations have become a significant supply of timber products (Thomas et al. 2009). Eucalyptus has become one of the most planted genera, as a result of their high rates of productivity and their adaptability to many different sites and climatic conditions. Such capabilities make eucalypts a prime candidate for energy production, primarily focusing on increasing yield through short rotation crops (Mead 2005). In these crops, productivity losses as a result of attack of insects could be significant. Reduction in productivity in Eucalyptus spp., as a result of insect damage has been measured in Australia, where many native insects attack Eucalyptus spp. plantations (Jordan et al. 2002, Rapley et al. 2009). However, increasing outbreaks of pest insects are a threat to eucalyptus plantations in many countries outside Australia (Wingfield et al. 2008).

Kulman (1971), in a review on the effect of insect defoliation on growth and mortality of trees, concluded that insect damage resulted in mortality, growth loss, rotation delays and increased tree susceptibility to other insect pests and diseases. Insect damage to shoots and branches can also lead to subsequent defects in the trunk that reduce merchantability in trees grown for saw lumber (Alfaro 1989).

Although it is certain that debarking caused by Ectinogonia buquetti did not produce plant death, it did result in an important decrease in foliar surface area. The estimations presented here indicate that between $11.6 \%$ and 28.6 $\%$ of photosynthetic leaf area will be lost on average due to ring-debarking caused by the insect during the first year after plantation establishment; which causes a decrease of between $3.5 \%$ and $18.0 \%$ of the total foliar area in the experimental units. Most likely, the damage caused by this insect will directly affect the biomass accumulation rate of the trees affected. The magnitude of this effect is still unknown; therefore we recommend the monitoring of affected trees over time in order to describe the decrease in biomass yield in comparison to unaffected trees.

In three year old Eucalyptus globulus plantations, Pinkard et al. (2006) found that $20 \%$ of tree defoliation caused by Gonipterus scutellatus resulted in significant reductions in the diameter growth 12 months after defoliation. Growth impacts should also be related not just to the level of defoliation but also to the location and timing of defoliation. Pinkard (2002), for Eucalyptus nitens and Pinkard et al. (2006), working on Eucalyptus globulus found that top of crown defoliation has a more severe impact on growth than the lower crown defoliation; early season defoliation has less impact than that presented by late season for Eucalyptus regnans (Candy 2000).

Apparently, there is an environmental effect on both the frequency of damaged trees as well as the proportion of foliar area lost at the experimental unit level, which is evidenced by a significant effect of blocks. The wind protected and more humid block, and probably with more healthy trees, was the one with the lowest damage by Ectinogonia buquetti. Coinciding with the results observed in the analysis of plantation density; the higher the attack frequency, the more significant the damage produced by the insect at the tree level. There is no evidence of interaction between block and plantation density, therefore the effects of both factors are additive.

However, Régolini et al. (2014) found that there is no effect between tree density and the probability of attack of Thaumetopoea pityocampa on pure stands of Pinus pinaster between four and 61 years of age. These authors found that trees were more likely to be affected on edge plots than on inner plots, and the chance of attack increases with tree diameter; suggesting that taller trees were more likely to be attacked than smaller ones.

In this study, and during site preparation and trials establishment, the adult insects were found in the field. However, adult insects were detected at native forest fragments in ravines, using exotic plantations to feed and reproduce. According to Régolini et al. (2014), it is probable that feeding resources (Eucalyptus camaldulensis trees) were abundant enough regarding Ectinogonia buquetti population, ensuring that females were able to find suitable habitats throughout the landscape. However, these assumptions could not be tested with data collected in this study, but may allow the design of future research in this area.

Insect outbreak rarely affects all trees within a plot, resulting in a non-uniform or more heterogeneous plot. According to (Binkley et al. 2002) this will affect productivity by increasing intra-specific competition, reducing tree size class distribution, increasing mortality and affecting site resource use efficiency.

This study provides new evidence supporting the hypothesis that Ectinogonia buquetti attacks on individual trees result from mechanisms acting at two different scales. At the plot scale, there was a positive relationship between the percentage of infested trees and stocking. At the individual tree scale, the probability of attack is higher in trees located inside wind-protected areas and in wetter plots. These new findings will help to improve the monitoring of Ectinogonia buquetti at a time at which this species is spreading rapidly to new forest areas.

\section{REFERENCES}

Alfaro RI. 1989. Stem defects in Sitka spruce induced by Sitka spruce weevil, Pissodes strobi (Peck). In XVIII International Congress of Entomology. Vancouver, Canada. Proceedings. p. 177-185.

Bertran J, E Morales. 2008. Potencial de generación de energía por residuos del manejo forestal en Chile. Santiago, Chile. Comisión Nacional de Energía (CNE)/Deutsche Gesellschaft für Technische Zusammenarbeit (GTZ) GmbH. 56 p.

Binkley D, JL Stape, MG Ryan, HR Barnard, J Fownes. 2002. Age- 
related decline in forest ecosystem growth: An individualtree, stand-structure hypothesis. Ecosystems 5(1): 58-67.

Candy SG. 2000. Predictive models for integrated pest management of the leaf beetle Chrysophtharta bimaculata in Eucalyptus nitens plantations in Tasmania. Tesis Doctor of Philosophy. Hobart, Australia. University of Tasmania. 472 p.

Carrasco P, J Millán, L Peña. 1993. Suelos de la cuenca del río Bío Bío: características y problemas de uso. In Faranda F, O Parra eds. Gestión de los recursos hídricos de la cuenca del río Bío-Bío y del área marina costera adyacente. Concepción, Chile. Universidad de Concepción. p. 12-108.

DGAC (Dirección General de Aeronáutica Civil, CL). 2013. Descripción Climatológica. Consulted May 08. Available in http://www.meteochile.cl/climas/climas.html

Eyles A, KM Barry, A Quentin, EA Pinkard. 2013. Impact of defoliation in temperate eucalypt plantations: Physiological perspectives and management implications. Forest Ecology and Management 304(0): 49-64.

Gara R, L Cerda, M Donoso. 1980. Manual de entomología forestal. Valdivia, Chile. Universidad Austral, Facultad de Ingeniería Forestal. 61 p.

INFOR (Instituto Forestal, CL). 2012. Anuario Forestal 2012: Boletín Estadístico 136. Santiago, Chile. Instituto Forestal. $138 \mathrm{p}$.

Jordan GJ, BM Potts, AR Clarke. 2002. Susceptibility of Eucalyptus globulus ssp. globulus to sawfly (Perga affinis ssp. insularis) attack and its potential impact on plantation productivity. Forest Ecology and Management 160(1-3): 189-199.

Kulman HM. 1971. Effects of insect defoliation on growth and mortality of trees. Annual Review of Entomology 16(1): 289-324.

Ley 20257. 2008. Ley 20257: Introduce modificaciones a la ley general de servicios eléctricos respecto de la generación de energía eléctrica con fuentes de energías renovables no convencionales. Santiago, Chile.

Mead DJ. 2005. Forests for energy and the role of planted trees. Critical Reviews in Plant Sciences 24(5-6): 407-421.

Moore T. 1994. Revisión del género Ectinogonia Spinola para Chile (Coleóptero, Buprestidae). Boletín de la Sociedad de
Biología de Concepción 65: 153-166.

Pinkard EA. 2002. Effects of pattern and severity of pruning on growth and branch development of pre-canopy closure $\mathrm{Eu}$ calyptus nitens. Forest Ecology and Management 157(13): 217-230.

Pinkard EA, C Baillie, V Patel, CL Mohammed. 2006. Effects of fertilising with nitrogen and phosphorus on growth and crown condition of Eucalyptus globulus Labill. experiencing insect defoliation. Forest Ecology and Management 231(1-3): 131-137.

Piontelli E, MA Palma, T L. 2006. Ectinogonia buquetti Spinola (Coleoptera) vector de Ophiostoma stenoceras (Robak) Melin et Nannf, en bosques de Eucalyptus de la V Región. Boletín Micológico 21: 63-70.

Rapley LP, BM Potts, M Battaglia, VS Patel, GR Allen. 2009. Long-term realised and projected growth impacts caused by autumn gum moth defoliation of 2-year-old Eucalyptus nitens plantation trees in Tasmania, Australia. Forest Ecology and Management 258(9): 1896-1903.

Régolini M, B Castagneyrol, A-M Dulaurent-Mercadal, D Piou, J-C Samalens, H Jactel. 2014. Effect of host tree density and apparency on the probability of attack by the pine processionary moth. Forest Ecology and Management 334(0): 185-192.

SAS Institute Inc. 2009. SAS/STAT® 9.2 User’s Guide. Cary, NC. SAS Institute Inc. 7886 p.

Thomas D, M Henson, B Joe, S Boyton, R Dickson. 2009. Review of growth and wood quality of plantation-grown Eucalyptus dunnii Maiden. Australian Forestry 72(1): 3-11.

Valdebenito B, S Sandoval, E Esquivel, E Acuña, M Espinosa, J Cancino, R Rubilar, F Muñoz, L Cerda. 2009. First report of Ectinogonia buquetti (Spin.) (Coleoptera: Buprestidae) in bioenergy plantations of Eucalyptus camaldulensis (Dehnh.) in Chile. New Forests 38(3): 241-244.

Wingfield MJ, B Slippers, BP Hurley, TA Coutinho, BD Wingfield, J Roux. 2008. Eucalypt pests and diseases: growing threats to plantation productivity. Southern Forests: a Journal of Forest Science 70(2): 139-144.

Zar JH. 2010. Biostatistical analysis. Upper Saddle River, N.J., USA. Prentice-Hall/Pearson. 944 p. 